\title{
Assessment of Irrigated Agriculture Vulnerability under Climate Change in Southern Italy
}

\author{
Sara Masia ${ }^{1,2, *}$, Janez Sušnik ${ }^{2}$ (D), Serena Marras ${ }^{1,3}$, Simone Mereu ${ }^{1,3}$, Donatella Spano ${ }^{1,3}$ \\ and Antonio Trabucco 1,3 \\ 1 Department of Agriculture, University of Sassari, 07100 Sassari, Italy; serenam@uniss.it (Se.M.); \\ simone.mereu@cmcc.it (Si.M.); spano@uniss.it (D.S.); antonio.trabucco@cmcc.it (A.T.) \\ 2 Integrated Water Systems and Governance Department, IHE Delft Institute for Water Education, \\ PO Box 3015, 2601 DA Delft, The Netherlands; j.susnik@un-ihe.org \\ 3 Euro-Mediterranean Center on Climate Changes, IAFES Division, 07100 Sassari, Italy \\ * Correspondence: s.masia@un-ihe.org; Tel.: +39-320-539-4881
}

Received: 18 December 2017; Accepted: 11 February 2018; Published: 15 February 2018

\begin{abstract}
Climate change in Mediterranean countries is anticipated to have a strong impact on water availability by exacerbating drought conditions and water scarcity. In this context, efficient irrigation practices are becoming essential for sustaining crop production. This work assesses vulnerability of irrigated agriculture for six irrigation districts and their associated reservoirs in Mediterranean areas across Italy under climate change (1976-2005 versus 2036-2065; RCP 4.5 and 8.5), evaluating changes in irrigation requirements, evaporation from reservoirs, and the availability of freshwater supplies. Irrigation requirements are estimated through a crop water model (SIMETAW_R) integrated into a GIS platform, while inflows to reservoirs are hydrologically modelled as partitioning of precipitation contributing to runoff. Results are aggregated into indicators that show the general decreasing resilience and increasing vulnerability of irrigated agriculture under climate change conditions in each case study. The highest percentage of allowable water losses for irrigation is estimated in the Cuga-Alto Temo system, during the prolonged drought period, to be able to satisfy irrigation demand for less than a year. Climate change may only partially affect irrigation in resilient systems, in which storage capacity and the water level entering into the reservoir are considerably higher than the water distribution volumes.
\end{abstract}

Keywords: Mediterranean; reservoirs; water scarcity; irrigation requirement; evaporation; resilience

\section{Introduction}

Changes in hydrological cycles are expected to be more severe in the 21st century due to increasing temperatures and the saturation vapor pressure [2]. According to the phrase "the wet get wetter and the dry get dryer", precipitation is projected to considerably decrease in already dry areas, such as subtropical zones [3].

Climate models estimate a likely decrease in total seasonal and annual rainfall over Mediterranean areas, with increased risks of prolonged dry seasons and drought periods together with extreme precipitation events (short duration, high intensity events) [4]. Reduction in precipitation totals leads to challenges in water availability in Southern Europe that may trigger a competition among sectors for water use, making it difficult to find a balance between demand and supply [5]. A fast growing population, urbanization, industrial development, and changing lifestyles lead to larger freshwater requirements [6-8], as well as increasing demand for food quantity and quality $[9,10]$. According to Alexandratos et al. [11], global agricultural productions are expected to increase by $60 \%$ by 2050 .

Water use in agriculture accounts for $70 \%$ globally and more than $80 \%$ in the Mediterranean basin [9]; however, it is essential to ensure food security and stimulate rural socio-economic 
development [12]. Water availability in the Mediterranean basin is a key factor for food security in this region [9]. Most of the water for irrigation in the region is derived from either surface or groundwater. However, costs for pumping groundwater are usually higher than those for using (subsidized) surface water from reservoirs, which represents most of the water used by irrigation districts. Groundwater is used outside irrigation districts or when surface water from reservoirs is scarce. For instance, in Sardinia, $69.4 \%$ of total water abstraction is allocated for agricultural use, and, specifically, $75 \%$ is provided by surface water and $25 \%$ by groundwater [13].

Cultivated area in Italy covers about 9 Mha, of which 4 Mha are equipped for irrigation and 2.8 Mha are actually irrigated. Specifically, total areas equipped for surface, sprinkler, and localized irrigation account for 2.4 Mha, 0.98 Mha, and 0.57 Mha, respectively. The total agricultural water withdrawal is equal to about $13 \mathrm{Bm}^{3}$ year ${ }^{-1}$ (billion cubic meters per year) [14]. About $24 \%$ of the Italian irrigated area is cultivated with maize, followed by temporary and permanent grass $(15 \%)$, rice $(12 \%)$, fruit trees $(9 \%)$, vegetables in open fields $(9 \%)$, vineyards $(8 \%)$, olives $(6 \%)$, cereals $(5 \%)$, citrus $(5 \%)$, and others [15].

Recently, several studies have highlighted the increasing irrigation demand of Mediterranean crops due to changing climate [16-24]. Increasing temperatures and water deficits have been identified as the main factors influencing changes in crop growth and yield. Prolonged drought periods and more frequent extreme events lead to marked hydrological imbalances and exacerbated water shortages, mostly in EU Southern regions [25]; thus, studies focusing on the sustainability and vulnerability of irrigated agriculture systems are becoming essential [26-28].

Both river discharge and water demand of irrigated agriculture are already simultaneously affected by climate change [29-31]. It is widely known that the physical processes (evaporation, transpiration, and condensation) involved in the water cycle are influenced by the variation of the climate parameters, which are mostly driven by the increasing concentration of greenhouse gas emissions (GHGs) in the atmosphere $[5,32,33]$. One of the most serious consequences of raising temperature is the acceleration of the evapotranspiration process that modifies crop water requirement, and therefore irrigation scheduling [34].

A key element in the future estimation of risk for irrigated agriculture under climate change requires an evaluation of the vulnerability and resilience of reservoir systems to withhold changing crop water demand [26]. The risk of water scarcity in water supply systems is related to drought intensity, infrastructure capacity, and adaptation policies in case of drought events. This environmental and socio-economic issue is particularly exacerbated in the Mediterranean region [35]. Garrote et al. [36] analyzed more than sixty basins in Southern Europe, and showed great differences in irrigation system vulnerability across Europe, highlighting particularly significant vulnerabilities in the Iberian Peninsula and in some parts of Italy and Greece.

This work aims to contribute to the elaboration of a methodological framework that assesses the vulnerability of reservoir-fed irrigated agriculture systems in Mediterranean areas under climate change, focusing in particular on case studies in Southern Italy. The simultaneous impact of climate change on both crop water demand, water inflows to reservoirs, and water losses due to evaporation are assessed to define the impact on water fluxes and availability, together with the future level of adequacy of reservoir infrastructures to sustain irrigated agriculture and food security. Results are aggregated in terms of indicators that evaluate different aspects of resilience and vulnerability related to climate change.

\section{Materials and Methods}

Irrigated agriculture vulnerability in Southern Italy was assessed by estimating the changes of irrigation requirements in agricultural districts and the water availability in associated reservoirs, as a result of climate change. The total water inflow to reservoirs was estimated as the product of upstream basin area, mean annual precipitation falling over the reservoir, and the basin runoff coefficient. The total water volume used to supply crop water needs was accounted for by computing the irrigated 
hectares in the irrigation district (Ir-Ds), and the crop irrigation requirements of representative crops, which are evaluated by irrigation models. The cumulated water shortage (CWS) in the reservoir under climate change conditions was computed by adding changes in water entering reservoirs, changes in water used for irrigation, and evaporation losses from baseline conditions to future projections (Equation (1)):

$$
\mathrm{CWS}=\Delta Q W I-(\Delta Q W D+\Delta E)
$$

in which $\triangle Q W I\left(\mathrm{Mm}^{3}\right)$ is the change in annual water volume entering in the reservoir between future and baseline periods, $\triangle Q W D\left(\mathrm{Mm}^{3}\right)$ is the change in annual water volume used for irrigation for a combination of representative crops, and $\Delta E\left(\mathrm{Mm}^{3}\right)$ is the change in annual reservoir surface evaporation. A schematic overview of the system is shown in Figure 1.

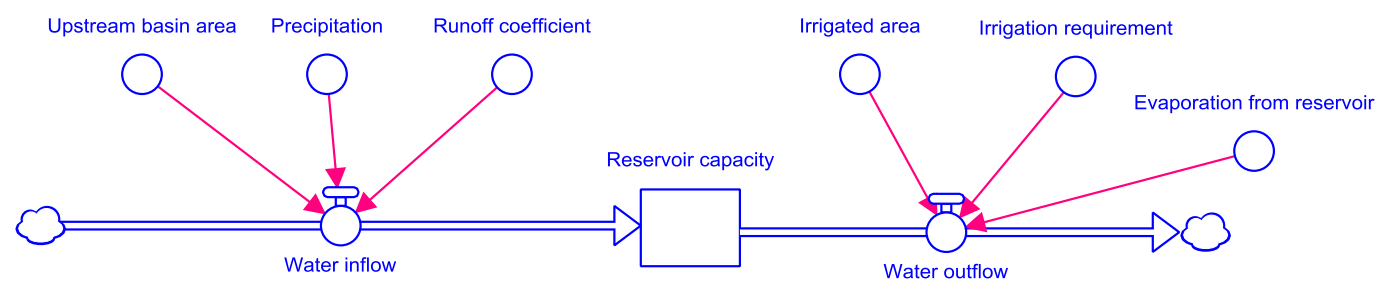

Figure 1. Scheme of the system structure used to estimate the reservoir water balance.

\subsection{Selected Reservoirs}

Six reservoirs in Southern Italy with irrigation as the main water use were selected from the Global Reservoir and Dam (GranD) database (version 1.1), developed by Lehner et al. [37], with each reservoir supplying a specific irrigation district or two, as in the case of San Giuliano reservoir (Table 1 and Figure 2). Another case study presents the situation in which two reservoirs (Alto Temo and Cuga) collectively supply water to the Nurra irrigation district. The GranD dataset is combined with a near global digital river network (HydroSHEDS) developed by Lehner et al. [38] to provide additional hydrological information for the reservoir. Relevant attributes present in the GranD dataset are used to characterize some physical dimensions of the selected reservoirs (e.g., Reservoir Maximum Capacity and Reservoir Surface Area). The use of extensive datasets, such as the GranD and others presented below, allows for easier transferability to larger areas and other case studies.

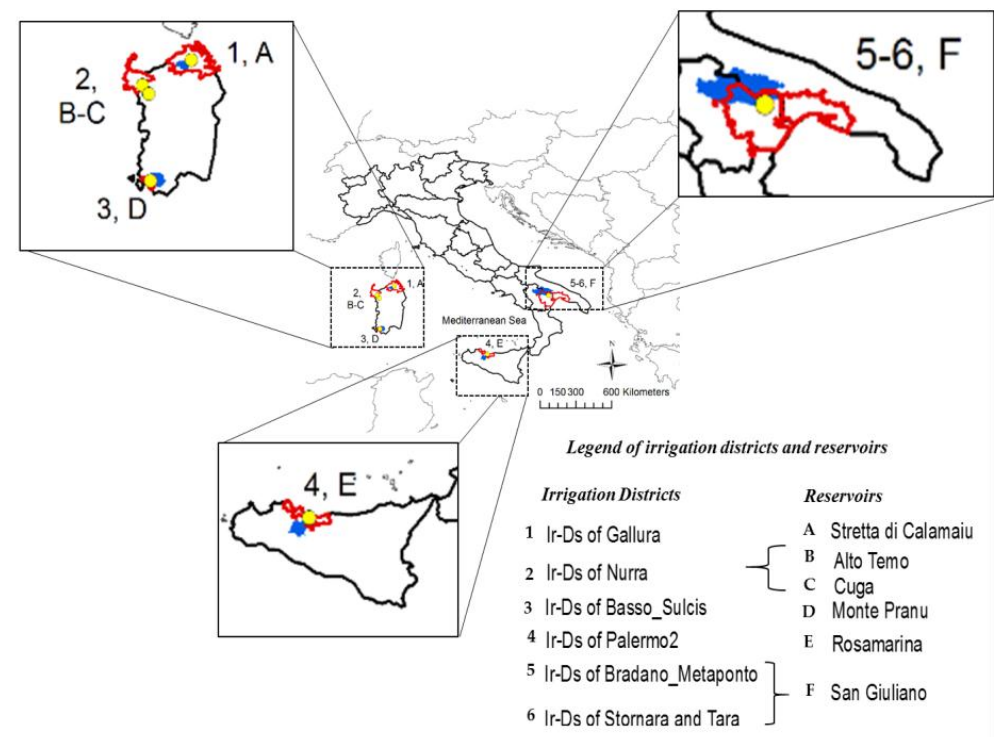

Figure 2. Reservoirs (yellow points), irrigation districts (red perimeters), and basins (blue areas) selected in the Mediterranean areas of Southern Italy. 
Table 1. Selected Italian reservoirs with irrigation as main use (data from Lehner et al. [38]).

\begin{tabular}{|c|c|c|c|c|c|c|c|c|}
\hline Reservoir & $\begin{array}{l}\text { Irrigation } \\
\text { District }\end{array}$ & $\begin{array}{l}\text { Municipalities } \\
\left(\mathbf{N}^{\circ}\right)\end{array}$ & $\begin{array}{l}\text { Administrative } \\
\text { Unit }\end{array}$ & $\begin{array}{c}\text { Reservoir } \\
\text { Maximum } \\
\text { Capacity }\left(\mathrm{Mm}^{3}\right)\end{array}$ & $\begin{array}{l}\text { Reservoir } \\
\text { Surface } \\
\text { Area }\left(\mathrm{km}^{2}\right)\end{array}$ & $\begin{array}{l}\text { Elevation } \\
\text { (m.a.s.1.) }\end{array}$ & $\begin{array}{l}\text { Lon } \\
\left({ }^{\circ} \mathrm{E}\right)\end{array}$ & $\begin{array}{l}\text { Lat } \\
\left({ }^{\circ} \mathrm{N}\right)\end{array}$ \\
\hline $\begin{array}{l}\text { Stretta di } \\
\text { Calamaiu }\end{array}$ & Gallura & $17[39]$ & Sardinia & 105.2 & 5.70 & 170 & 9.27 & 41.01 \\
\hline Cuga & Nurra & $5[40]$ & Sardinia & 31.7 & 3.00 & 101 & 8.45 & 40.61 \\
\hline Alto Temo & Nurra & $5[40]$ & Sardinia & 95.7 & 4.99 & 242 & 8.56 & 40.47 \\
\hline Monte Pranu & Basso Sulcis & $6[41]$ & Sardinia & 62 & 6.98 & 42 & 8.59 & 39.09 \\
\hline Rosamarina & Palermo 2 & $16[42]$ & Sicily & 100 & 5.41 & 153 & 13.64 & 37.95 \\
\hline San Giuliano & $\begin{array}{c}\text { Stornara and } \\
\text { Tara; Bradano } \\
\text { Metaponto }\end{array}$ & $24[43]+31[44]$ & $\begin{array}{l}\text { Apulia and } \\
\text { Basilicata }\end{array}$ & 107 & 10.14 & 100 & 16.53 & 40.6 \\
\hline
\end{tabular}

\subsection{Climate Data}

Climate data at daily time step were retrieved from the Global Circulation Model (GCM) CMCC-MED (coupled model of atmosphere-ocean-sea-ice with a focus on Mediterranean region developed by the Euro-Mediterranean Center on Climate Change) $[45,46]$, downscaled to a spatial resolution of $14 \mathrm{~km}$ with the regional climate model COSMO-CLM (Consortium For Small scale Modeling in Climate Mode) [47]. The climate baseline condition refers to the period 1976-2005, while climate data for the intermediate future (2036-2065) under both Representative Concentration Pathway (RCP, [48]) 4.5 and 8.5 scenarios were used in this work as climate projections.

\subsection{Total Water Inflow}

The total water inflow to the reservoir was estimated for the baseline (1976-2005) and future (2036-2065) climate conditions, under RCP 4.5 and 8.5 scenarios, by the product of upstream basin area, mean annual precipitation falling over the upstream basin (over the considered periods), and a basin runoff coefficient.

\subsubsection{Reservoir Upstream Basin Area}

The reservoir upstream basin area was derived by using a digital elevation model (DEM) developed by the Shuttle Radar Topographic mission (SRTM) and gap filled from CSI-CGIAR (Consortium for Spatial Information), globally available at $90 \mathrm{~m}$ resolution [49]. The ESRI ARCGIS v. 10.5 hydro-tool [50] was used to calculate the basin (or watershed) area over specific reservoirs. Firstly, the original DEM input raster was gap-filled for digital sinkless approximation of elevation. Secondly, the raster of flow direction for any specific cell to its steepest downslope neighbor was created. Then, the flow direction grid was used to create a raster of flow accumulation, i.e., a raster counting the number of accumulated contributing pixels flowing into each cell. Finally, the upstream catchment area was calculated as the contributing area above the reservoirs.

\subsubsection{Runoff Coefficient}

The runoff coefficient is the relative partitioning of precipitation that contributes to runoff and streamflow. It was statistically computed (Equation (2)) for the whole Euro-Mediterranean basin on a yearly average and then applied to the selected basin reservoirs. This is the ratio between gridded mean composite dataset of runoff field, obtained through the combination of observed river discharge with simulated water balance [51], and gridded mean of precipitation from Willmott et al. [52] database, both computed over the 1950 to 2000 period at spatial resolution of $30 \mathrm{~min}$ (Figure 3).

$$
\mathrm{Rc}=\frac{\text { Total runoff }}{\text { Total precipitation }}
$$


Runoff coefficient values range from 0 to 1 , in which high values are specific to areas with low infiltration, such as steep slopes and pavements; reversely low values are characteristic of permeable, flat, and/or vegetated areas [53].

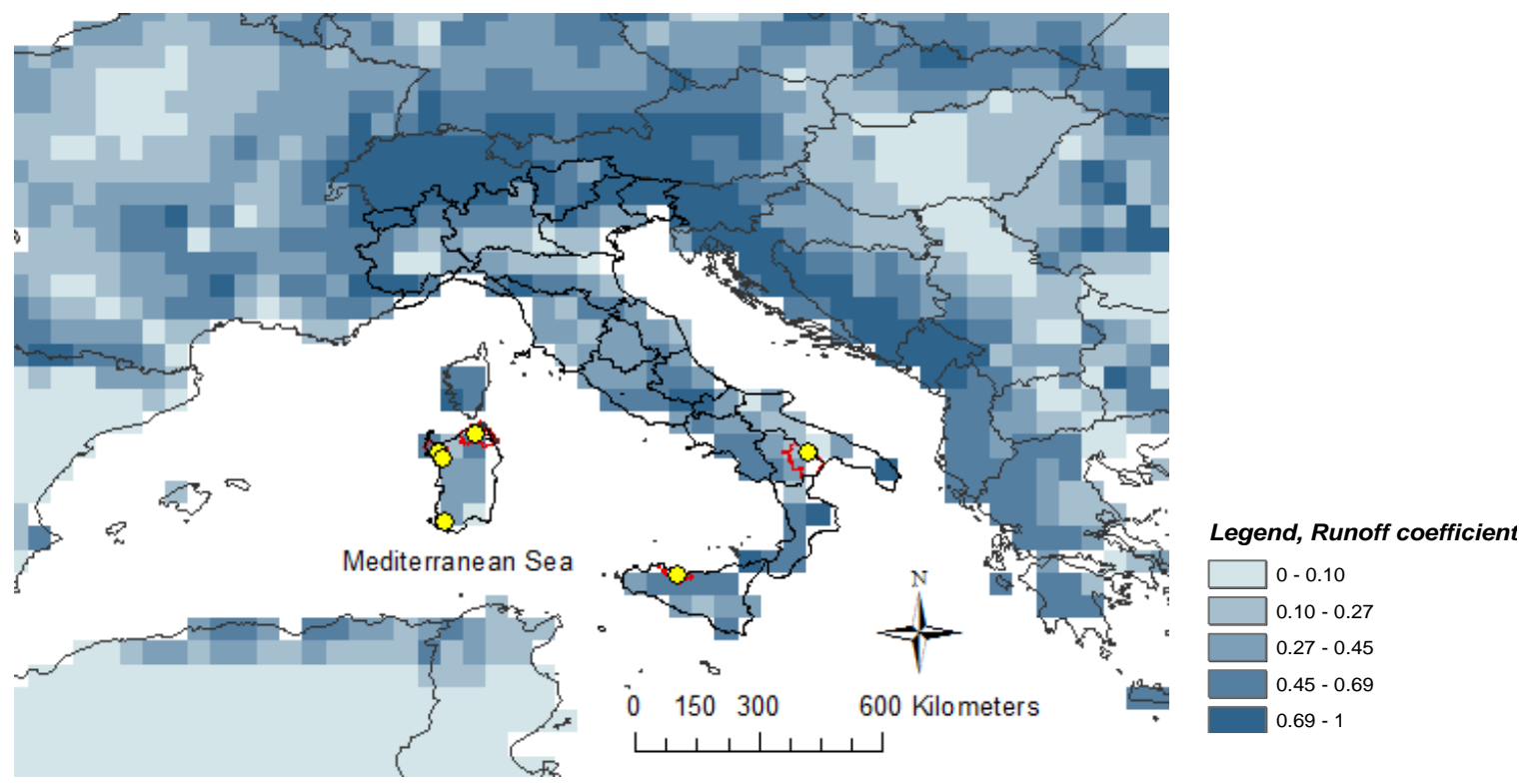

Figure 3. Map of the runoff coefficient obtained as the ratio of total runoff to total precipitation values with irrigation districts (red perimeters, legend in Figure 2) and reservoirs (yellow points, legend in Figure 2).

Values were validated around study areas by comparing observed and modelled data (Table 2). Observed data were derived from literature. Once again, a general method in conjunction with large scale database was preferred to allow applying the methodology over other and larger areas.

Table 2. Comparison of observed (Rc_obs) and simulated (Rc_sim) runoff coefficient for specific Italian reservoir upstream basins.

\begin{tabular}{ccccccc}
\hline Reservoir & Country & Lat $^{\circ} \mathbf{N}$ & Lon & \\
& & $\mathbf{E}$ & Rc_Obs & Rc_Sim & Literature \\
\hline Pedra'E Othoni & Italy & 40.32 & 9.54 & 0.40 & 0.46 & {$[28]$} \\
Coghinas & Italy & 40.93 & 8.80 & 0.25 & 0.26 & {$[54]$} \\
Flumendosa & Italy & 39.43 & 9.61 & 0.32 & 0.34 & {$[54]$} \\
Temo & Italy & 40.47 & 8.56 & 0.45 & 0.42 & {$[55]$} \\
Cuga & Italy & 40.61 & 8.45 & 0.36 & 0.42 & {$[55]$} \\
Stretta di Calamaiu & Italy & 41.01 & 9.27 & 0.35 & 0.45 & {$[55]$} \\
San Giuliano & Italy & 40.6 & 16.53 & 0.22 & 0.35 & {$[56]$} \\
\hline
\end{tabular}

\subsection{Evaporation from Open Water}

The computation of the water evaporation from reservoirs was based on the Penman Monteith approach simplified by Jensen [57] (Equation (3)).

$$
\Delta E=\frac{\Delta(R n-Q t)+\gamma E a}{\Delta+\gamma}
$$

in which $\Delta E$ is the latent heat of vaporization $\left(\mathrm{MJ} \mathrm{m}{ }^{-2} \mathrm{t}^{-1}\right), \gamma$ the psychometric constant $\left(\mathrm{kPa}^{\circ} \mathrm{C}^{-1}\right)$, $\Delta$ the saturation vapor pressure at $T_{a}$ temperature $\left(\mathrm{kPa}^{\circ} \mathrm{C}^{-1}\right), R n$ the net radiation, $Q t$ the change in energy storage ( $\mathrm{MJ} \mathrm{m}^{-2} \mathrm{t}^{-1}$ ), and $E a$ the bulk aerodynamic formula based on a wind function $\left(\mathrm{MJ} \mathrm{m} \mathrm{m}^{-2} \mathrm{t}^{-1}\right)$. 
The climate data and the digital elevation model described in Sections 2.2 and 2.3.1, respectively, were used to run simulations for the baseline and the future climate conditions under RCP 4.5 and 8.5. Evaporation values were multiplied by the reservoir surface area $\left(\mathrm{km}^{2}\right)$ in each reservoir (Table 1) and expressed in million cubic meters $\left(\mathrm{Mm}^{3}\right)$.

\subsection{Total Water Distribution}

The total water volume used to supply crop water needs was accounted by assessing the areal distribution of the different irrigated crop types for each Ir-Ds (Table 3) and the associated modelled irrigation requirements with the Simulation of Evapotranspiration of Applied Water (SIMETAW) for the most relevant crop types for each specific study area and growing season [58] as described below.

\subsubsection{Crop Irrigation Requirements and Applications-SIMETAW_GIS Platform}

The SIMETAW_R model is an improved version of SIMETAW\# model developed by the University of California, Davis, and the California Department of Water Resources [59,60] and recently modified by Mancosu et al. [61]. SIMETAW\# is a daily soil water balance program developed to compute the reference, crop, and actual evapotranspiration (ETo, ETc, and ETa, respectively), as well as the number of irrigation events, and the amount of water applied per each event (net application; NA) [61] on a local scale. The original model was re-written using "R" language (SIMETAW_R; https:/ / www.rproject.org/) and, secondly, associated with GIS libraries (SIMETAW_GIS platform), which couples and automates interaction with climate and environmental input data to process simulations of soil water balance for multiple years and pixels across regional and continental assessments, and calculates spatial distribution of yearly crop water consumption and irrigation requirements. Data are integrated and processed from multiple NetCDF and GIS files.

Climate, crop, soil, and management input data are required to run simulations with the model. Specifically, daily weather data such as maximum and minimum temperature $\left({ }^{\circ} \mathrm{C}\right)$, wind speed $\left(\mathrm{m} \mathrm{s}^{-1}\right)$, solar radiation $\left(\mathrm{MJ} \mathrm{m}^{-2} \mathrm{day}^{-1}\right)$, dew point temperature $\left({ }^{\circ} \mathrm{C}\right)$, or relative humidity $(\%)$ were used to compute ETo following the standardized reference evapotranspiration equation for short canopies $[62,63]$. The crop water requirement of a specific crop, in a specific area, was estimated, including the precipitation, the crop planting and harvesting date, the presence of cover crops, the soil water holding capacity, the maximum rooting depth, the maximum soil depth, and the percentage of full area planted. Information on irrigation system, water allocation, and distribution uniformity was also included in the model [59-61] to derive the final net application (NA), used in the further estimates of agriculture water demand.

\subsubsection{Total District Irrigation}

The total irrigation requirement for the most relevant crops cultivated in each irrigation district was computed following Masia [58], with a focus on the specific areas under investigation.

In this context, maize grape, wheat, peach, and tomato mean water demand were estimated using SIMETAW_GIS platform to assess the impact of climate change in the areas served by the selected reservoirs for the baseline (1976-2005) and future (2036-2065) climate conditions, under RCP 4.5 and 8.5 scenarios, using the same climate model projections as presented in Section 2.2. Tomato and peach were considered as representative for vegetable and fruit crops, respectively.

Crop irrigation requirements of the abovementioned crops constitute a majority of irrigated crop distribution and were divided by the fraction of their distribution over the total irrigated area in each Ir-Ds ([64]; Table 3) to upscale the total irrigation abstraction (i.e., of all crop types) for the baseline and future scenarios. Each reservoir supplies water to one irrigation district, except for San Giuliano reservoir, which serves two districts, specifically the Bradano Metaponto in Basilicata region and Stornara and Tara in Apulia region (Figure 2). The total annual water volume provided by this reservoir for irrigation is $40 \mathrm{Mm}^{3}$, and it is equally allocated between the two regions as an average of $50 \%$ in each [65]. 
Table 3. Distribution of the main and the total irrigated crops in each irrigation districts in hectares $[64,66]$.

\begin{tabular}{|c|c|c|c|c|c|c|}
\hline \multirow{2}{*}{ Irrigated Crops } & \multicolumn{6}{|c|}{ Irrigation District } \\
\hline & Gallura & Nurra & Basso Sulcis & Palermo 2 & Bradano-Metaponto & Stornara and Tara \\
\hline Maize & 25 & 466 & 12 & 0.05 & 392 & 129 \\
\hline Grape & 327 & 1160 & 97 & 49 & 1368 & 7156 \\
\hline Fruit trees & 12 & 66 & 6 & 130 & 8075 & 47 \\
\hline Vegetables & 84 & 697 & 912 & 910 & 2704 & 1673 \\
\hline Wheat & 53 & 202 & 105 & 35 & 1649 & 0 \\
\hline $\begin{array}{c}\text { Most relevant crops } \\
\text { (i.e., sum of the } \\
\text { above) }\end{array}$ & 501 & 2591 & 1131 & 1125 & 14,188 & 9005 \\
\hline All crops & 1402 & 4704 & 1382 & 3826 & 25,202 & 13,203 \\
\hline
\end{tabular}

\subsection{Irrigation System Resilience and Vulnerability}

A measure of reservoir resilience is given by its annual recharge capacity. The recharge indicator $(R I)$ was developed to provide a measure of the extent to which a reservoir can be (re)charged on average over a year once irrigation water and open water evaporation have been accounted for. It is computed as the ratio between net annual water inflow into the reservoir and maximum reservoir capacity (Cap MCM) (Equation (4)). Ratios less than one imply that recharge is not, on average, able to completely recharge the reservoir once irrigation and evaporation are accounted for.

$$
\text { Recharge indicator }(\mathrm{RI})=\frac{W I-(W D+E)}{\text { Cap } M C M}
$$

in which WI is the annual water volume inflow in the reservoir $\left(\mathrm{Mm}^{3}\right), W D$ is the annual water volume used to satisfy irrigation demand $\left(\mathrm{Mm}^{3}\right)$, and $E$ is the annual water volume evaporated from the reservoir open body water surface $\left(\mathrm{Mm}^{3}\right)$.

The vulnerability of the reservoir to recharge or maintain its water stock in the future (Equation (5)) is calculated as the relative difference between the change between future and past recharge indicator value compared to the present.

$$
\text { Vulnerability indicator }(\mathrm{VI})=\frac{R I(\text { future })-R I(\text { baseline })}{R I(\text { baseline })}
$$

The greater the difference between current and future states, the greater the change in vulnerability depending on the direction of change.

Classes of Resilience and Vulnerability

The recharge indicator was defined by five classes of resilience (Table 4) developed in this work to assess the status and the trend of the reservoir over a period.

Table 4. Classes of reservoir resilience, definitions, and values.

\begin{tabular}{ccc}
\hline Class of Resilience & Definition & Value \\
\hline A & Highly resilient & $R I>1$ \\
B & Resilient & $0.50 \leq R I \leq 1$ \\
C & Moderately resilient & $0.20 \leq R I \leq 0.50$ \\
D & Slightly resilient & $0 \leq R I \leq 0.20$ \\
E & No resilient & $R I<0$ \\
\hline
\end{tabular}


The higher the net annual volume entering into the reservoir for a given reservoir capacity, the higher is the irrigated agriculture's resilience to climate change. On an equal net water inflow, reservoirs characterized by a smaller capacity show a higher annual recharge and thus a greater resilience. However, reservoir capacity should be weighted theoretically to match water demand. Increasing values of annual water outflow and decreasing values of annual water inflow leads to a reduction in resilience. A lack of resilience is shown when the annual mean outflow is not compensated for by an annual water amount entering into the reservoir higher or at least equal to water outflow.

The same number of classes used for resilience are also developed and used to determine the reservoir vulnerability under climate change conditions. Values range from Not vulnerable $(V I>0)$ to Highly vulnerable $(V I<-1)$ (Table 5$)$.

Table 5. Classes of reservoir vulnerability to climate change, definitions, and values.

\begin{tabular}{ccc}
\hline Class of Vulnerability & Definition & Value \\
\hline A & Highly vulnerable & $V I<-1$ \\
B & Vulnerable & $-1 \leq V I \leq-0.5$ \\
C & Moderately vulnerable & $-0.50 \leq V I \leq-0.20$ \\
D & Slightly vulnerable & $-0.20 \leq V I \leq 0$ \\
E & Not vulnerable & $V I>0$ \\
\hline
\end{tabular}

For a given cumulated water change for irrigation demand and reservoir water inflow, a change in stress is presented to irrigation system. Values of change in water inflow higher than changes in water outflow lead to a reduction in vulnerability of the irrigation system for a given reservoir capacity. The opposite is also true: increases in demand and a drop in inflow leads to an increase in vulnerability. The reservoir vulnerability to future climate changes is directly proportional to the index of vulnerability. Reservoirs with larger capacity relative to water demand are generally considered more resilient to adsorb water budget changes [28].

\subsection{Temporal Self-Sufficiency in Demand Capacity (TSSDC)}

Assuming strong changes in precipitation patterns, owing to prolonged drought after an average year of rainfall, the Temporal Self-Sufficiency in Demand Capacity (TSSDC) index measures forhow long a given reservoir could supply the requisite irrigation and evaporation requirements under the assumption of a complete cut off in reservoir inflow. When the volume available for recharge is higher than the reservoir maximum capacity, the number of years is estimated as the ratio between reservoir capacity and the sum of the water used for irrigation and the water evaporated from the surface of the reservoir (Equation (6)).

$$
\mathrm{TSSDC}=\text { if }\left(W I>\operatorname{Cap} M C M ; \frac{\operatorname{Cap} M C M}{(W D+E)} ; \frac{W I-(W D+E)}{(W D+E)}\right)(\text { year })
$$

For reservoirs with a higher recharge volume and lower demands, this time will be longer than the opposite situation.

The TSSDC indicator shows a measure of irrigated agriculture resilience, and its estimation is particularly relevant in areas characterized by high climatic variability such as the Mediterranean basin.

In terms of vulnerability, this is again expressed as a relative change to baseline conditions (Equation (7)).

$$
\operatorname{TSSDC}_{V I}=\frac{\operatorname{TSSDC}(\text { future })-\mathrm{TSSDC}(\text { baseline })}{\operatorname{TSSDC}(\text { baseline })}
$$

The larger the change, the greater the change in vulnerability, with the direction of change reflecting the change in vulnerability where positive values represent a decrease in the system vulnerability and vice-versa. 


\subsection{Allowable Water Losses for Irrigation (AWLI)}

The Allowable Water Losses for Irrigation (AWLI) represent the theoretical maximum allowable water losses in an irrigation distribution system that would result in all the inflow being used (i.e., leaving a net zero recharge to the reservoir) (Equation (8)).

$$
\mathrm{AWLI}=\text { if }\left(\text { WI }>\text { Cap } M C M ; 100 \times\left[1-\left(\frac{W D}{\operatorname{Cap} M C M-E}\right)\right] ; 100 \times\left[1-\left(\frac{W D}{W I-E}\right)\right]\right)
$$

The related vulnerability indicator (Equation (9)) highlights the need for improvement in system efficiency that would be required to offset future climate and irrigation changes in order to maintain baseline system efficiencies.

$$
\mathrm{AWLI}_{V I}=\frac{\operatorname{AWLI}(\text { future })-\mathrm{AWLI}(\text { baseline })}{\mathrm{AWLI}(\text { baseline })}
$$

\section{Results}

\subsection{Reservoir Water Inflow}

Precipitation in the future is expected to decrease over all the reservoirs under study by $5-20 \%$, with lowest decreases in the eastern part of Sardinia (5-10\%) and strongest on the western part of Sardinia and peninsular part of Southern Italy (10-20\%). Decreases are projected to be stronger under RCP 8.5, except in the Cuga and Alto Temo basins (eastern Sardinia), where strongest reductions in precipitation are projected under RCP 4.5. The mean basin annual precipitation values ranged from 492 to $378 \mathrm{~mm}$ year ${ }^{-1}$ for the baseline, and the highest differences between future and past values are computed in Stretta di Calamaiu (northern Sardinia) and San Giuliano (peninsular Southern Italy) reservoirs under RCP 8.5, with the lowest in Alto Temo. The largest mean annual inflow (WI) values (in San Giuliano) are related to its large basin draining area $\left(1634 \mathrm{~km}^{2}\right)$, which is considerably larger than Rosamarina $\left(529 \mathrm{~km}^{2}\right)$ and Monte Pranu $\left(420 \mathrm{~km}^{2}\right)$. Rosamarina (Sicily) and Monte Pranu (southern Sardinia) basins have similar precipitation but very different runoff coefficients, resulting in twice as much water inflow in Rosamarina than Monte Pranu. Monte Pranu basin, in Southern Sardinia, receives the lowest precipitation among all the selected case studies in Southern Italy. Compared to the baseline, the strongest water inflow reduction is estimated for San Giuliano, especially under RCP 8.5, while limited reductions are expected for the Cuga-Alto Temo system. Stretta di Calamaiu and Alto Temo show the most water entering per basin $\mathrm{km}^{2}$ (about $0.20 \mathrm{Mm}^{3}$ ), along with Rosamarina (about $0.18 \mathrm{Mm}^{3}$ ), where values are related to the higher runoff coefficient. The lowest water inflow per $\mathrm{km}^{2}$ characterizes reservoirs with a combination of low precipitations and runoff coefficient, such as in Monte Pranu and San Giuliano. Slightly lower water inflow per $\mathrm{km}^{2}$ in Cuga reservoir is explained by the lower mean annual precipitation (Table 6).

Table 6. Mean annual precipitation $\left(\mathrm{mm} \mathrm{year}^{-1}\right)$, basin area $\left(\mathrm{km}^{2}\right)$, runoff coefficient, and reservoir water inflow (WI, $\mathrm{Mm}^{3}$ year $^{-1}$ ) in the selected reservoirs for the baseline (1976-2005) and future

\begin{tabular}{|c|c|c|c|c|c|c|c|c|}
\hline \multirow{3}{*}{ Reservoirs } & \multicolumn{3}{|c|}{ Basin Annual Precipitation } & \multirow{2}{*}{ Basin Area } & \multirow{3}{*}{$\begin{array}{c}\text { Runoff } \\
\text { Coefficient }\end{array}$} & \multicolumn{3}{|c|}{ Reservoir Water Inflow } \\
\hline & baseline & RCP 45 & RCP 85 & & & Baseline & RCP 45 & RCP 85 \\
\hline & $\mathrm{mm}$ & $\mathrm{mm}$ & $\mathrm{mm}$ & $\mathrm{km}^{2}$ & & $\begin{array}{c}\mathrm{Mm}^{3} \\
\text { year }^{-1}\end{array}$ & $\begin{array}{c}\mathrm{Mm}^{3} \\
\text { year }^{-1}\end{array}$ & $\begin{array}{c}\mathrm{Mm}^{3} \\
\text { year }^{-1}\end{array}$ \\
\hline $\begin{array}{l}\text { Stretta di } \\
\text { Calamaiu }\end{array}$ & 492 & 423 & 407 & 339 & 0.45 & 75 & 65 & 62 \\
\hline Cuga & 436 & 393 & 412 & 73 & 0.42 & 13 & 12 & 13 \\
\hline Alto Temo & 476 & 447 & 464 & 124 & 0.42 & 25 & 23 & 24 \\
\hline Monte Pranu & 378 & 349 & 318 & 420 & 0.32 & 51 & 47 & 43 \\
\hline Rosamarina & 386 & 350 & 324 & 529 & 0.50 & 102 & 93 & 86 \\
\hline San Giuliano & 448 & 379 & 352 & 1634 & 0.35 & 256 & 217 & 201 \\
\hline
\end{tabular}
(2036-2065) climate conditions, under RCP 4.5 and 8.5 scenarios. 


\subsection{Reservoir Water Outflow: Irrigation Requirement}

The Gallura and Basso Sulcis irrigation districts, both having a similar irrigated area, see a similar crop water demand (WD) for the baseline (about $6 \mathrm{Mm}^{3}$ ), and similar difference between future and baseline total water outflow for irrigation $\left(0.43-0.57 \mathrm{Mm}^{3}\right.$ or $\sim 8-10 \%$, Figure 4$)$. The total irrigated area is more than double in Palermo 2 and, consequently, the total water abstracted from the reservoir to satisfy crop water needs is proportional $\left(17 \mathrm{Mm}^{3}\right)$, with a sensible future increase due to climate changes (about $1 \mathrm{Mm}^{3}$ ). The greatest differences between past and future water abstraction are expected in Bradano Metaponto (about 1.8 and $3 \mathrm{Mm}^{3}$ or $4.8 \%$ and $8.3 \%$, respectively, for RCP 4.5 and RCP 8.5). Differences between RCPs in agriculture water requirements are generally quite limited for most case studies, except for Bradano Metaponto (1.3 $\mathrm{Mm}^{3}$ or $3.4 \%$ ) (Table 7).

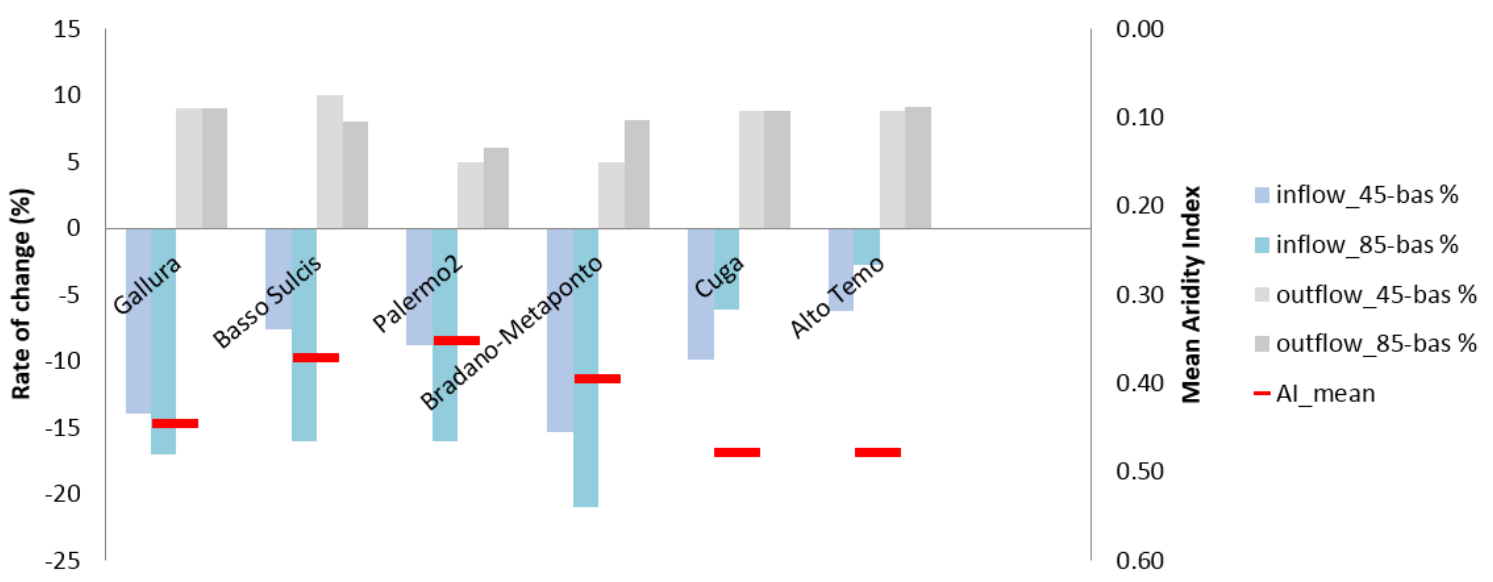

Figure 4. Rate of change in water inflow and outflow between future under RCP 4.5 and 8.5 (bars, left axis), and baseline together with the aridity index (lines, right axis). Aridity Index (AI) is calculated as the ratio of annual precipitation over reference evapotranspiration, and is displayed as average over the 1976-2005 period (AI mean). Data are shown per each Ir-Ds.

Table 7. Crop water demand $(W D)$ and evaporation from the open surface, in each case study. Values are expressed in $\mathrm{Mm}^{3}$ and shown for the baseline and future period, under RCP 4.5 and 8.5 scenarios.

\begin{tabular}{|c|c|c|c|c|c|c|c|}
\hline \multirow{3}{*}{ Irrigation District } & \multirow{3}{*}{ Reservoir } & \multicolumn{2}{|c|}{ Baseline } & \multicolumn{2}{|c|}{ RCP 4.5} & \multicolumn{2}{|c|}{ RCP 8.5} \\
\hline & & WD & $\mathbf{E}$ & WD & $\mathbf{E}$ & WD & $\mathbf{E}$ \\
\hline & & \multicolumn{2}{|c|}{$\mathrm{Mm}^{3}$} & \multicolumn{2}{|c|}{$\mathrm{Mm}^{3}$} & \multicolumn{2}{|c|}{$\mathrm{Mm}^{3}$} \\
\hline Gallura & Stretta di Calamaiu & 5.77 & 5.15 & 6.30 & 5.66 & 6.28 & 5.84 \\
\hline Nurra & Cuga-Alto Temo & 20.07 & 7.54 & 21.84 & 8.22 & 21.80 & 8.38 \\
\hline Basso Sulcis & Monte Pranu & 5.62 & 7.11 & 6.18 & 7.67 & 6.05 & 7.86 \\
\hline Palermo 2 & Rosamarina & 16.79 & 5.46 & 17.67 & 5.75 & 17.73 & 5.98 \\
\hline Bradano Metaponto & San Giuliano & 37.1 & 11.82 & 38.9 & 11.91 & 40.2 & 13.39 \\
\hline
\end{tabular}

\subsection{Evaporation from Reservoirs Surface}

The highest amount of evaporation from the open surface is computed in San Giuliano reservoir, especially under the worst scenario (i.e., RCP 8.5). Annual values range from 7 to $8 \mathrm{Mm}^{3}$ in Monte Pranu and Cuga-Alto Temo systems, and are lower in Stretta di Calamaiu and Rosamarina (5-6 $\left.\mathrm{Mm}^{3}\right)$. The lowest and the highest difference in evaporation losses due to climate change are both computed in San Giuliano reservoir ( 0.09 and 1.57 under RCP 4.5 and 8.5, respectively). In addition, low differences were also estimated in Cuga reservoir under both RCPs scenario (0.26-0.32) and in Rosamarina (0.29) under RCP 4.5 (Table 7). 


\subsection{Resilience and Vulnerability of the Irrigated Agriculture}

In this work the mean annual recharge capacity was estimated to assess the resilience of each reservoir (Equation (4)), and to evaluate the vulnerability of the irrigated agriculture in the districts under climate change conditions (Equation (5)). The highest resilience (class A, Table 4) was shown by San Giuliano, whose inflow in the baseline and under both RCPs is able to completely recharge the reservoir for a total amount that is almost double its capacity. Nevertheless, the vulnerability of irrigated agriculture in Bradano Metaponto and Stornara and Tara districts is expected to increase from class $D$ to class $C$ (Tables 5 and 8), due to the strong cumulated water shortage (about $-41 \mathrm{Mm}^{3}$ and $-60 \mathrm{Mm}^{3}$ under RCP 4.5 and 8.5, respectively). The same trend is also observed in Stretta di Calamaiu and Monte Pranu reservoirs that are characterized by a certain level of resilience (class B, Table 4 ) in the baseline and under RCP 4.5, which is expected to decrease (class C, Table 4) under the worst scenario.

The Gallura and Basso Sulcis districts are characterized by similar changes of crop water demand $\left(0.43 \mathrm{Mm}^{3} \leq \mathrm{WD} \leq 0.56 \mathrm{Mm}^{3}\right)$ and evaporation $\left(0.51 \mathrm{Mm}^{3} \leq \mathrm{E} \leq 0.75 \mathrm{Mm}^{3}\right)$ between future and past, while lower values of water inflow changes were estimated in Stretta di Calamaiu $\left(-10 \mathrm{Mm}^{3} \leq \mathrm{WI}\right.$ $\left.\leq-13 \mathrm{Mm}^{3}\right)$ than in Monte Pranu $\left(-4 \mathrm{Mm}^{3} \leq \mathrm{WI} \leq-8 \mathrm{Mm}^{3}\right)$, where a consequent lower recharge capacity is estimated.

Despite the reduction of recharge capacity estimated in Rosamarina reservoir under climate change, its resilience does not change over the considered periods, while instead its vulnerability is expected to decrease due to an increased cumulated water shortage. The lowest resilience (class D, Table 4) in both baseline and future climate conditions and the highest vulnerability (class C, Table 5) is estimated in Nurra district served by the Cuga-Alto Temo system that is able to annually recharge only the $8 \%$ of the reservoir during the baseline, and values tend to decrease under RCPs (about $-4 \%$ ).

\subsection{Temporal Reservoir Self-Sufficiency in Prolonged Drought Conditions}

A measure of the irrigated agriculture resilience to climate change is estimated through the Temporal Self-Sufficiency in Demand Capacity index (Equation (6)). Under prolonged drought conditions, the Cuga-Alto Temo system is the most vulnerable $\left(-0.56 \leq \mathrm{TSSDC}_{V I} \leq-0.40\right)$ (Table 7) due to its low recharge capacity and the increasing values of water required to irrigate the fields (4704 ha) in Nurra district. The system is able to satisfy irrigation demand for less than one year. Rosamarina is presently able to supply water for about 3.5 years and would not be able to supply water for more than 2.9 or 2.6 years under future climate with vulnerability values that ranged from -0.17 to -0.27 under RCP 4.5 and 8.5 , respectively. Similar vulnerability values were estimated in Monte Pranu reservoir (Table 8). The most resilient (almost 5 years in the baseline and about 4.3 under future climate) is Stretta di Calamaiu, and it is explained by the small irrigated crop distribution in Gallura district. Although San Giuliano is characterized by a high recharge capacity, it is estimated to supply water for no longer than about 2.2 years, and its level of resilience is related to the large irrigated area served both in Basilicata and Puglia regions. Since inflows remain higher than the reservoir max capacity in the future, and differently for all other systems, its vulnerability is mainly due to increases in irrigation requirements and open body evaporation. Regarding other reservoirs, the vulnerability is higher under RCP 8.5 scenario. 
Table 8. Differences of annual water inflow (WI), crop water demand (WD), evaporation loss $(E)$, cumulated water shortage (CWS), vulnerability index (VI), Temporal Self-sufficiency in Demand Capacity index (TSSDC), and Allowable Water Losses for Irrigation index (AWLI). Changes are reported between baseline (b, 1976-2005) and future (2036-2065) climate under RCP 4.5 and 8.5.

\begin{tabular}{|c|c|c|c|c|c|c|c|c|c|c|}
\hline \multirow{3}{*}{ Reservoir } & \multicolumn{2}{|c|}{ Gallura } & \multicolumn{2}{|c|}{ Nurra } & \multicolumn{2}{|c|}{ Basso Sulcis } & \multicolumn{2}{|c|}{ Palermo 2} & \multicolumn{2}{|c|}{$\begin{array}{c}\text { Bradano Metaponto } \\
\text { Stornara and Tara }\end{array}$} \\
\hline & \multicolumn{2}{|c|}{ Stretta di Calamaiu } & \multicolumn{2}{|c|}{ Cuga-Alto Temo } & \multicolumn{2}{|c|}{ Monte Pranu } & \multicolumn{2}{|c|}{ Rosamarina } & \multicolumn{2}{|c|}{ San Giuliano } \\
\hline & $4.5-b$ & $8.5-b$ & $4.5-b$ & $8.5-b$ & $4.5-b$ & $8.5-b$ & $4.5-b$ & $8.5-b$ & $4.5-b$ & $8.5-b$ \\
\hline $\begin{array}{l}\text { Maximum Capacity } \\
\qquad\left(\mathrm{Mm}^{3}\right)\end{array}$ & \multicolumn{2}{|c|}{105.2} & \multicolumn{2}{|c|}{127.4} & \multicolumn{2}{|c|}{62} & \multicolumn{2}{|c|}{100} & \multicolumn{2}{|c|}{107} \\
\hline WI $\left(\mathrm{Mm}^{3}\right)$ & -10 & -13 & -3 & -1 & -4 & -8 & -9 & -16 & -39 & -55 \\
\hline $\mathrm{WD}\left(\mathrm{Mm}^{3}\right)$ & 0.53 & 0.51 & 1.77 & 1.73 & 0.56 & 0.43 & 0.88 & 0.94 & 1.8 & 3 \\
\hline $\mathrm{E}\left(\mathrm{Mm}^{3}\right)$ & 0.51 & 0.69 & 0.68 & 0.84 & 0.56 & 0.75 & 0.29 & 0.52 & 0.09 & 1.57 \\
\hline CWS $\left(\mathrm{Mm}^{3}\right)$ & -11.04 & -14.20 & -7.08 & -5.69 & -5.02 & -9.25 & -10.26 & -17.55 & -40.89 & -59.57 \\
\hline VI (fraction) & -0.17 & -0.23 & -0.53 & -0.35 & -0.13 & -0.24 & -0.13 & -0.22 & -0.20 & -0.29 \\
\hline TSSDC-VI (fraction) & -0.24 & -0.30 & -0.56 & -0.40 & -0.20 & -0.30 & -0.17 & -0.27 & -0.04 & -0.09 \\
\hline$A W L I-V I(\%)$ & -2.57 & -3.18 & -45.92 & -30.14 & -3.34 & -5.06 & -3.46 & -5.77 & -3.16 & -6.49 \\
\hline
\end{tabular}

\subsection{Water Losses and Improvement of System Efficiency}

In this work, AWLI of most reservoirs was higher than 75\% except for the Cuga-Alto Temo and the San Giuliano system. However, these two dams have a low AWLI because of different reasons: In the Cuga-Alto Temo, it is related to the fact that all water inflow can be hardly used for irrigation demand (e.g., rainfall concentrated in limited period of the year), especially if the reservoir capacity is quite limited. In the San Giuliano System, the main cause is that available water does not strictly depend on the inflow but on the reservoir maximum capacity.

Water losses through system efficiency improvements should decrease by about $45 \%$ and $30 \%$ in Cuga-Alto Temo system under RCP 4.5 and RCP 8.5, respectively. In all the other reservoirs, percentage improvements required are almost double under RCP 8.5 compared with RCP 4.5, except for Stretta di Calamaiu, which shows almost the same values under both RCPs (Table 8).

The rate of change in water inflow and outflow between future under both RCPs and baseline is shown in Figure 4, together with the climatic classification of each of the Ir-Ds computed following United Nations Environment Programme (UNEP) [67] classification.

The rate of change between future and past water inflow ranges from about 16 to $22 \%$ under the worst scenario in all Ir-Ds, except for the Cuga-Alto Temo system, which, in contrast to the other basins, is mainly affected under RCP 4.5. The rate of change of the total water used to supply agricultural needs is slightly different in each case study, particularly in Gallura, Palermo 2, and Nurra (about 0.20-0.36). The highest difference between future and past is estimated in Bradano Metaponto and Stornara and Tara, where the percentage was up to about $4 \%$.

\section{Discussion}

In this work, we have proposed a set of indicators that can be used to quickly assess operational criticalities of reservoirs to sustainably fulfill irrigation water demands for specific irrigation districts. Specifically, the analysis was conducted in Italy where the negative simultaneous effect of increasing temperature and decreasing water availability on crop water demand was widely argued $[16,68]$, particularly in the South [16,69-71].

The changes in reservoir water inflow are reported for each basin, together with changes in agriculture water demand and losses for evaporation.

The highest resilience is estimated in correspondence with the highest recharge capacity (e.g., San Giuliano system), while highest vulnerability is for the lowest recharge capacity (Cuga-Alto Temo system). Vulnerability tends to increase as a function of water deficit, while resilience is mostly related to storage capacity, but also to water use efficiency in the irrigation system and system 
management capacity. In this regard, the system shows also high vulnerability with relative changes under future climate of allowable water losses for irrigation (ranging from about $-45 \%$ to $-30 \%$ for Cuga-Alto Temo).

In each case study in this work, irrigated agriculture is defined under some degrees of vulnerability. The proposed vulnerability indicators do not account for interannual variability in precipitations, which is relevant, especially for those reservoirs that have an average low inflow but a high capacity (such as the Cuga and alto Temo system). Nevertheless, they allow us to identify vulnerability issues of different origins based on a standardized methodology. According to the methodology proposed, in general most reservoirs studied are considered resilient to climate change despite the decreasing projected future mean precipitation, and its portioning into runoff, and future crop water demand increases. This is mostly due to their storage capacity, which is sufficient to buffer the irrigation water demand during dry seasons. This is an important finding for local water and reservoir managers: the reservoir size itself generally is sufficient to allow for resilience to future input and demand changes. However, imbalances between water demand and supply have occurred in some of these systems, suggesting that water management and/or infrastructures do not allow for the most efficient resource use. In this sense, the vulnerability indicators should be seen as a degree of intervention in infrastructures and water use policies that are to be added to the present needs. The indicators and the classes developed in this work may support policies promoting the sustainability of the water use preserving the available natural resource in the long-term (Article 1, Water Framework Directive 2000/60/EC (WFD) [72]) and address the development of monitoring programmes and measures aimed to investigate and control both surface and groundwater status (Article 8 and 11, WFD [72]). In addition, they might be used to analyze the main features of the river basin districts as well as the anthropogenic impact (Article 5, WFD [72]). Particularly, the results and the approach related to both recharge and vulnerability indicators (RI and VI), as well as the estimation of the improvements in system efficiency $\left(\mathrm{AWLI}_{V I}\right)$ may be considered in the achievement of the European purpose target to reduce water use for irrigation of the $40 \%$ by enhancing water use efficiency [73]. The knowledge of the $\operatorname{TTSSD}_{V I}$ value can be useful to support socio-economic decisions that aim to increase water saving in agriculture, such as the shift to "more-drought resistant" crops, thus saving water and contemporarily reducing yield losses as aimed for by the European Commission. As a result, the work in this paper is more widely applicable, and directly relevant for WFD considerations and monitoring.

Although agriculture consumes most water, other sectors also depend on these water resources-a degree of competition that is likely to increase in the future. Mean annual precipitation in Italy in the period 2000-2009 (763 $\mathrm{mm}_{\text {year }}{ }^{-1}$ ) had been lower by about $30 \mathrm{~mm}$ than in the period 1971-2000, and further decrease is expected for the future in Southern Italy [74], particularly in Sardinia [75]. This risk confirms the need to identify both vulnerability and resilience of Italian reservoirs.

As in this work, reservoir resilience to climate change in a case study located in the eastern part of Sardinia was expected by Mereu et al. [28]. However, a reduction of future reservoir performance under climate change conditions in South Italy was assessed by Longobardi et al. [76], who stated that the failure of the systems was mainly due to the reduction of available water rather than reservoir capacity. The latter was instead the main issue for the systems analyzed in the work by Preziosi et al. [77]. The issue of declining availability (supply) is perhaps more critical, therefore, than demand increases for some reservoirs. However, it is important to consider that water volume distributions may be affected by water losses in the irrigation systems (up to $50 \%$ of water distribution losses for irrigated agriculture), while it is important to maintain or retain a percentage of flow for ecosystems (minimum environmental flow up to $10 \%$ of streamflow) in compliance with the EU water directive. In this context, according to Stakhiv and Stewart [78], the largest driver of vulnerability is the inadequate infrastructures, for which more efforts that aim to improve water management are required. Climate change impact, irrigated crop distribution, and changes in cropping patterns may become the key factors that influence future irrigation demand in Mediterranean areas. Policies aimed at reducing the 
risk of water scarcity in supply system mainly due to drought intensity and infrastructure capacity and/or adequacy should be developed.

\section{Limitation and Constrains of the Work}

In this work, our indicators for future periods are mostly driven by climatic changes and several assumptions were made. This implies some constrains and limitations.

The proposed indicators do not account for changes in irrigated area and crop distribution, so they rather provide a quantitative dimension of criticalities (e.g., water use efficiency/saving) that must be solved for the sustainable expansion of the irrigated agricultural sector. For example, the indicators for the Cuga-Alto Temo system suggest that only because of climate change (according to the used projections), an improvement of water use efficiency in the order of $30-45 \%$ would be required to maintain actual irrigated distribution, where any expansion of irrigated agricultural area implies a higher water efficiency in that system. Population is not expected to change significantly in Southern Italy [79], and local crop food demand is therefore expected to be stable. However, much of the future changes in irrigated agricultural area may be dependent on exports to EU and global markets driven by socio-economic factors. In this sense, the application of these indicators at large scale could be useful to describe trends of some relevant drivers (water for agriculture), which may be at stake in analyses of socio-economic growth of the food-crop market.

Runoff coefficients were estimated based on extrapolated maps of streamflow observations for the historical period to give a standard annual partition of rainfall into runoff. This hydrological simplification is helpful to generate annual estimates, in a process which is easily replicable in other study areas and multiple projections; this was one of the main objectives for these indicators: to sustain more comprehensive future studies on a large scale. More complex hydrological models would more realistically represent hydrological processes on a finer temporal scale, but would be extremely cumbersome when applied to multiple sites and projections.

Environmental flows are not taken into account, since the management of reservoirs is prioritized to satisfy human needs. Although it is recommended to maintain a minimum environmental flow generally up to $10 \%$ of streamflow, this is usually (and unfortunately) not considered or limited with reduced reservoir water levels.

In addition, we recognize that, indeed, over the course of a year, not all the water that enters a reservoir is available for use-the cumulative runoff cannot all be stored, and there is inevitable spillage. However, we developed our indicators in relation to long term drought management. Under drought conditions, proportionally more runoff can then stored in the reservoir for use and management.

Furthermore, it should be stressed that most of the water used in the irrigation districts is provided by surface water, which is available to farmers at lower costs (subsidized) to farmers than groundwater (higher pumping costs). Groundwater could become a relevant source of water in irrigation districts whenever water levels in reservoirs are scarce.

\section{Conclusions}

In this work, the irrigated agriculture vulnerability under climate change conditions was assessed by comparing estimates for the baseline (1976-2005) and the future period (2036-2065), under RCP 4.5 and 8.5, for six irrigation districts located in Mediterranean areas, and served by reservoirs whose main use is for irrigation. Grape, wheat, maize, vegetable, and fruit trees irrigation requirements are estimated on a regional scale using the SIMETAW_GIS platform in association with climate projections dynamically downscaled with RCM. Water distribution volumes used to irrigate the field in each of the Ir-Ds are computed considering both the crop irrigated area and irrigation requirements of the most representative crops.

A future water deficit is expected to characterize each irrigation district when a decreasing resilience and an increasing vulnerability of the reservoirs are estimated under climate change. The lowest resilience is estimated in the Cuga-Alto Temo system, while the highest is estimated 
in the San Giuliano reservoir, which is characterized by the highest recharge capacity. Resilience tends to increase as a function of water storing capacity and water use efficiency, while vulnerability is mainly related to water deficit.

The outcomes and the approach developed in our study may be used to increase awareness about climate change impact in the Mediterranean basin, but also to address farmers, institutions, and politicians in developing sustainable strategies to better manage water resources in the agricultural sector. The indicators and the classes developed in this work may be applied to supporting policies targeted at promoting sustainable water use (e.g., WFD, Water Notes).

The methodology applied may be extended to a more complex nexus that considers balances and dynamic flows between other resources such as land, food, and energy, and their feedback. An in-depth study on the vulnerability and resilience of Euro-Mediterranean reservoirs to climate change, as well as the assessment of potential future conflicts among the water-use sectors, use may be useful for addressing political decisions that aim to develop strategies to better manage water resources in irrigation districts.

Acknowledgments: Part of the work described in this paper has been conducted within the project SIM4NEXUS. This project has received funding from the European Union's Horizon 2020 research and innovation programme under Grant Agreement NO 689150 SIM4NEXUS. This paper and the content included in it do not represent the opinion of the European Union, and the European Union is not responsible for any use that might be made of its content. The authors are thankful to the three anonymous reviewers whose comments and advice contributed to significantly improving the manuscript.

Author Contributions: A.T., Sa.M., Si.M., J.S. conceived and designed the work. Sa.M. and A.T. performed the model simulations. Sa.M., A.T., J.S., and Si.M. analyzed the data. Se.M., and D.S. contributed analysis and material tools. Sa.M, J.S, Si.M, Se.M, D.S, A.T. wrote the paper.

Conflicts of Interest: The authors declare no conflict of interest.

\section{References}

1. Allen, R.G.; Pruitt, W.O.; Wright, J.L.; Howell, T.A.; Ventura, F.; Snyder, R.L.; Itenfisu, D.; Steduto, P.; Berengena, J.; Yrisarry, J.B.; et al. Recommendation on standardized surface resistance for hourly calculation of reference ETo by the FAO56 Penman-Monteith method. Agric. Water Manag. 2006, 81, 1-22. [CrossRef]

2. Huntington, T.G. Evidence for intensification of the global water cycle: Review and synthesis. J. Hydrol. 2006, 319, 83-95. [CrossRef]

3. Intergovernmental Panel on Climate Change (IPCC). Summary for Policymakers. In Climate Change 2013: The Physical Science Basis. Contribution of Working Group I to the Fifth Assessment Report of the Intergovernmental Panel on Climate Change; Stocker, T.F., Qin, D., Plattner, G.-K., Tignor, M., Allen, S.K., Boschung, J., Nauels, A., Xia, Y., Bex, V., Midgley, P.M., Eds.; Cambridge University Press: Cambridge, UK; New York, NY, USA, 2013.

4. Intergovernmental Panel on Climate Change (IPCC). Managing the Risks of Extreme Events and Disasters to Advance Climate Change Adaptation. A Special Report of Working Groups I and II of the Intergovernmental Panel on Climate Change; Field, C.B., Barros, V., Stocker, T.F., Qin, D., Dokken, D.J., Ebi, K.L., Mastrandrea, M.D., Mach, K.J., Plattner, G.-K., Allen, S.K., et al., Eds.; Cambridge University Press: Cambridge, UK; New York, NY, USA, 2012; p. 582.

5. Bates, B.C.; Kundzewicz, Z.W.; Wu, S.; Palutikof, J.P. Climate Change and Water; Technical Paper of the Intergovernmental Panel on Climate Change; IPCC Secretariat: Geneva, Switzerland, 2008; p. 210.

6. McDonald, R.I.; Green, P.; Balk, D.; Fekete, B.M.; Revenga, C.; Todd, M.; Montgomery, M. Urban growth, climate change, and freshwater availability. Proc. Natl. Acad. Sci. USA 2011, 108, 6312-6317. [CrossRef] [PubMed]

7. Harrison, P.A.; Dunford, R.; Savin, C.; Rounsevell, M.D.A.; Holman, I.P.; Kebede, A.S.; Stuch, B. Cross-sectoral impacts of climate change and socioeconomic change for multiple, European land-and water-based sectors. Clim. Chang. 2014. [CrossRef]

8. McDonald, R.I.; Weber, K.; Padowski, J.; Florke, M.; Schneider, C.; Green, P.A.; Gleeson, T.; Eckmann, S.; Lehner, B.; Balk, D.; et al. Water on an urban planet: Urbanization and the reach of urban water infrastructure. Glob. Environ. Chang. 2014, 27, 96-105. [CrossRef] 
9. Ferragina, E.; Canitano, G. Geopolitical Implications of Water and Food Security in Southern and Eastern Mediterranean Countries. In Building Sustainable Agriculture for Food Security in the Euro Mediterranean Area: Challenges and Policy Options; Paciello, M.C., Ed.; Edizioni Nuova Cultura for Istituto Affari Internazionali (IAI): Roma, Italy, 2014; pp. 33-56, ISBN 9788868125080.

10. Godfray, H.C.J.; Garnett, T. Food security and sustainable intensification. Philos. Trans. R. Soc. Lond. B Biol. Sci. 2014, 369. [CrossRef] [PubMed]

11. Alexandratos, N.; Bruinsma, J. World Agriculture towards 2030/2050: The 2012 Revision; ESA 2012. Working Paper 12-03; FAO: Rome, Italy, 2012.

12. Brooks, J. (Ed.) Agricultural Policies for Poverty Reduction; OECD Publishing: Paris, France, 2012.

13. ISRI. Le Risorse Idriche in Sardegna. In Programma Operativo Della Regione Autonoma Della Sardegna 2000-2006; Aggiornamento Della Valutazione Intermedia, V. 1.1; ISRI: Cagliari, Italy, 2008.

14. Food and Agriculture Organization of the United Nations (FAO). AQUASTAT Main Database, Food and Agriculture Organization of the United Nations (FAO). Available online: http:/ / www.fao.org/nr/water/ aquastat/data/query/index.html?lang=en (accessed on 1 September 2017).

15. EUROSTAT. Available online: http://ec.europa.eu/eurostat/statistics-explained/index.php/File:Figure_6_ Irrigated_area_by_type_of_crops_Italy_2010.PNG (accessed on 8 September 2017).

16. Tubiello, F.N.; Donatelli, M.; Rosenzweig, C.; Stockle, C.O. Effects of climate change and elevated $\mathrm{CO}_{2}$ on cropping systems: Model predictions at two Italian locations. Eur. J. Agron. 2000, 13, 179-189. [CrossRef]

17. Kapur, B.; Steduto, P.; Todorovic, M. Prediction of climatic change for the next 100 years in the Apulia region, Southern Italy. Ital. J. Agron. 2007, 4, 365-371. [CrossRef]

18. Rodriguez-Diaz, J.A.; Weatherhead, E.K.; Knox, J.W.; Camacho, E. Climate change impacts on irrigation water requirements in the Guadalquivir river basin in Spain. Reg. Environ. Chang. 2007, 7, 149-159. [CrossRef]

19. Yano, T.; Aydin, M.; Haraguchi, T. Impact of climate change on irrigation demand and crop growth in a Mediterranean environment of Turkey. Sensors 2007, 7, 2297-2315. [CrossRef] [PubMed]

20. Mancosu, N. Agricultural Water Demand Assessment Using the SIMETAW\# Model. Ph.D. Thesis, University of Sassari, Sassari, Italy, 2013.

21. Riediger, J.; Breckling, B.; Nuske, R.S.; Schröder, W. Will climate change increase irrigation requirements in agriculture of Central Europe? A simulation study for Northern Germany. Environ. Sci. Eur. 2014, 26, 1-13. [CrossRef] [PubMed]

22. Saadi, S.; Todorovic, M.; Tanasijevic, L.; Pereira, L.S.; Pizzigalli, C.; Lionello, P. Climate change and Mediterranean agriculture: Impacts on winter wheat and tomato crop evapotranspiration, irrigation requirements and yield. Agric. Water Manag. 2014, 147, 103-115. [CrossRef]

23. Tanasijevic, L.; Todorovic, M.; Pereira, L.S.; Pizzigalli, C.; Lionello, P. Impacts of climate change on olive crop evapotranspiration and irrigation requirements in the Mediterranean region. Agric. Water Manag. 2014, 144, 54-68. [CrossRef]

24. Gallo, A. Assessment of the Climate Change Impact and Adaptation Strategies on Italian Cereal Production Using High Resolution Climate Data. Ph.D. Thesis, University of Sassari, Sassari, Italy, 2015.

25. Intergovernmental Panel on Climate Change (IPCC). Summary for Policymakers. In Climate Change 2014: Mitigation of Climate Change. Contribution of Working Group III to the Fifth Assessment Report of the Intergovernmental Panel on Climate Change; Edenhofer, O., Pichs-Madruga, R., Sokona, Y., Farahani, E., Kadner, S., Seyboth, K., Adler, A., Baum, I., Brunner, S., Eickemeier, P., et al., Eds.; Cambridge University Press: Cambridge, UK; New York, NY, USA, 2014.

26. Nam, W.H.; Choi, J.Y. Development of an irrigation vulnerability assessment model in agricultural reservoirs utilizing probability theory and reliability analysis. Agric. Water Manag. 2014, 142, 115-126. [CrossRef]

27. Nam, W.H.; Choi, J.N.; Hong, E.M. Irrigation vulnerability assessment on agricultural water supply riskfor adaptive management of climate change in South Korea. Agric. Water Manag. 2015, 152, 173-187. [CrossRef]

28. Mereu, S.; Sušnik, J.; Trabucco, A.; Daccache, A.; Vamvakeridou-Lyroudia, L.; Renoldi, S.; Virdis, A.; Savić, D.; Assimacopoulos, D. Operational resilience of reservoirs to climate change, agricultural demand, and tourism: A case study from Sardinia. Sci. Total Environ. 2016, 543, 1028-1038. [CrossRef] [PubMed]

29. Yamba, F.D.; Walimwipi, H.; Jain, S.; Zhou, P.; Cuamba, B.; Mzezewa, C. Climate change/variability implications on hydroelectricity generation in the Zambezi River Basin. Mitig. Adapt. Strateg. Glob. Chang. 2011, 16, 617-628. [CrossRef] 
30. Meza, F.J.; Wilks, D.S.; Gurovich, L.; Bambach, N. Impacts of Climate Change on Irrigated Agriculture in the Maipo Basin, Chile: Reliability of Water Rights and Changes in the Demand for Irrigation. J. Water Resour. Plan. Manag. 2012, 138, 421-430. [CrossRef]

31. Kling, H.; Stanzel, P.; Preishuber, M. Impact modelling of water resources development and climate scenarios on Zambezi River discharge. J. Hydrol. Reg. Stud. 2014, 1, 17-43. [CrossRef]

32. European Environmental Agency (EEA). Water Quantity, River Floods and Droughts in Impacts of Europe's Changing Climate-2008 Indicator-Based Assessment; Joint EEA-JRC-WHO Report, EEA Report No 4/2008; European Environmental Agency, European Communities: Copenhagen, Denmark, 2008; ISBN 978-92-9167-372-8.

33. Stagl, J.; Mayr, E.; Koch, H.; Hattermann, F.F.; Huang, S. Effects of Climate Change on the Hydrological Cycle in Central and Eastern Europe. Chapter 3. In Managing Protected Areas in Central and Eastern Europe under Climate Change; Rannow, S., Neubert, M., Eds.; Advances in Global Change Research; Springer: Dordrecht, The Netherlands, 2014; Volume 58.

34. Hargreaves, G.H.; Riley, J.P.; Sikka, A. Influence of climate on irrigation, Canadian. Water Resour. J. 1993, 18, 53-59. [CrossRef]

35. Cancelliere, A.; Rossi, G. Drought and water scarcity risk in the Mediterranean. In Proceedings of the EC Expert Group on Water Scarcity and Drought, FEM, Venice, Italy, 13-14 October 2011.

36. Garrote, L.; Iglesias, A.; Granados, A.; Mediero, L.; Carrasco, F.M. Quantitative Assessment of Climate Change Vulnerability of Irrigation Demands in Mediterranean Europe. Water Resour. Manag. 2015, 29, 325-338. [CrossRef]

37. Lehner, B.; Reidy Liermann, C.; Revenga, C.; Vörösmarty, C.; Fekete, B.; Crouzet, P.; Döll, P.; Endejan, M.; Frenken, K.; Magome, J.; et al. High resolution mapping of the world's reservoirs and dams for sustainable river flow management. Front. Ecol. Environ. 2011, 9, 494-502. [CrossRef]

38. Lehner, B.; Verdin, K.; Jarvis, A. New global hydrography derived from spaceborne elevation data. Eos 2008, 89, 93-94. [CrossRef]

39. CBGallura. Consorzio di Bonifica Della Gallura. Available online: http://www.cbgallura.it/index.php? option=com_content\&view=article\&id=47\&Itemid=54 (accessed on 25 October 2017).

40. CBNurra. Consorzio di Bonifica Della Nurra. Available online: http://www.bonificanurra.it/index.php/ comprensorio/24-tavole.html (accessed on 25 October 2017).

41. CBBasso-Sulcis. Consorzio di Bonifica del Basso Sulcis. Available online: http://www.consorziobassosulcis. it/servizioirr.asp (accessed on 25 October 2017).

42. CBPalermo2. Available online: http://adpaloha.altervista.org/wpcontent/uploads/2012/10/ ROSAMARINA.pdf (accessed on 3 November 2017).

43. CBStornara and Tara. Available online: http://lnx.bonificastornaratara.it/page-una-colonna-php/ (accessed on 16 November 2017).

44. CBBradano-Metaponto. Available online: http://www.bradanometaponto.it/PianoClassifica.html (accessed on 16 November 2017).

45. Gualdi, S.; Somot, S.; Li, L.; Artale, V.; Adani, M.; Bellucci, A.; Braun, A.; Calmanti, S.; Carillo, A.; Dell'Aquila, A.; et al. The CIRCE simulations: Regional Climate Change Projections with Realistic Representation of the Mediterranean Sea. Bull. Amer. Meteor. Soc. 2013, 94, 65-81. [CrossRef]

46. Scoccimarro, E.; Gualdi, S.; Bellucci, A.; Sanna, A.; Fogli, P.G.; Manzini, E.; Vichi, M.; Oddo, P.; Navarra, A. Effects of tropical cyclones on ocean heat transport in a high resolution coupled general circulation model. J. Clim. 2011, 24, 4368-4384. [CrossRef]

47. Rockel, B.; Will, A.; Hense, A. The regional Climate Model COSMO-CLM (CCLM). Meteorol. Z. 2008, 17, 347-348. [CrossRef]

48. IPCC. Annex II: Glossary. In Climate Change 2014: Synthesis Report. Contribution of Working Groups I, II and III to the Fifth Assessment Report of the Intergovernmental Panel on Climate Change; Mach, K.J., Planton, S., von Stechow, C., Core Writing Team, Pachauri, R.K., Meyer, L.A., Eds.; IPCC: Geneva, Switzerland, 2014; pp. 117-130.

49. Jarvis, A.; Reuter, H.I.; Nelson, A.; Guevara, E. Hole-Filled SRTM for the Globe Version 4. The CGIAR-CSI SRTM 90 m Database. 2008. Available online: http:/ / srtm.csi.cgiar.org (accessed on 5 December 2017).

50. ESRI. ArcGIS Desktop: Release 10.5, Environmental Systems Research Institute: Redlands, CA, USA, 2013. 
51. Fekete, B.M.; Vörösmarty, C.J.; Grabs, W. Global, Composite Runoff Fields Based on Observed River Discharge and Simulated Water Balances; Report No. 22; Global Runoff Data Centre (GRDC), Federal Institute of Hydrology (BFG): Koblenz, Germany, 2000.

52. Willmott, C.J.; Matsuura, K. Terrestrial Air Temperature and Precipitation: Monthly and Annual Time Series (1950-1999). 2001. Available online: http://climate.geog.udel.edu/ climate/html_pages/README.ghcn_ ts2.html (accessed on 19 September 2017).

53. Florida Department of Transportation (FDOT). Drainage Handbook Hydrology; Florida Department of Transportation: Tallahassee, FL, USA, 2012.

54. RAS. Campagna di Sensibilizzazione per un Uso Consapevole e Amorevole Dell'acqua; Scheda No. 8. Progetto Altriponti, Osservatorio Mediterraneo: Un Ponte Dacqua; Regione Autonoma della Sardegna: Sassari, Italy, 2002.

55. Brandis, P. La Disponibilità idrica e la politica del territorio in Sardegna. In La Sardegna nel Mondo Mediterraneo: $1^{\circ}$ Convegno Internazionale di Studi Geografico-Storici, 7-9, 1979; Gallizzi: Sassari, Italy, 1981; p. 96.

56. CBBradano-Metaponto. Available online: www.bradanometaponto.it/SANGIULIANO.html (accessed on 16 November 2017).

57. Jensen, M.E. Estimating Evaporation from Water Surfaces. In Proceedings of the CSU/ARS Evapotranspiration Workshop, Fort Collins, CO, USA, 15 March 2010; pp. 1-27.

58. Masia, S. A Modeling Tool to Assess Local and Regional Impact of Climate Change on Crop Water Requirement in Euro-Mediterranean Countries, and Assessment of Mediterranean Irrigated Agriculture Vulnerability. Ph.D. Thesis, University of Sassari, Sassari, Italy, 2017.

59. Snyder, R.L.; Geng, S.; Orang, M.N.; Matyac, J.S.; Sarreshteh, S. A simulation model for ET of applied water. Acta Hortic. 2004, 664, 623-629. [CrossRef]

60. Snyder, R.L.; Geng, S.; Orang, M.; Sarreshteh, S. Calculation and Simulation of Evapotranspiration of Applied Water. J. Integr. Agric. 2012, 11, 489-501. [CrossRef]

61. Mancosu, N.; Spano, D.; Orang, M.; Sarreshteh, S.; Snyder, R.L. SIMETAW\#-A Model for Agricultural Water Demand Planning. Water Resour. Manag. 2016, 30, 541-557. [CrossRef]

62. Allen, R.G.; Pereira, L.S.; Raes, D.; Smith, M. Crop Evapotranspiration: Guidelines for Computing Crop Requirements; Irrigation and Drainage Paper No. 56; FAO: Rome, Italy, 1998; p. 300.

63. Allen, R.G.; Walter, I.A.; Elliott, R.L.; Howell, T.A.; Itenfisu, D.; Jensen, M.E. The ASCE Standardized Reference Evapotranspiration Equation; American Society of Civil Engineers: Reston, VA, USA, 2005.

64. ISTAT. Censimento Agricoltura. 2010. Available online: http://daticensimentoagricoltura.istat.it/Index. aspx?lang=it\# (accessed on 23 November 2017).

65. ADB Basilicata. Available online: http://www.adb.basilicata.it/adb/risorseidriche/invaso.asp?invaso= SGiuliano (accessed on 23 November 2017).

66. Ministero Delle Infrastrutture e dei Trasporti (MIT). Puglia: Il Sistema Idrico, a Cura di Guido Viceconte; MIT: Roma, Italy, 2003.

67. United Nations Environment Programme (UNEP). World Atlas of Desertification; Middleton, N., Thomas, D.S.G., Eds.; Edward Arnold: London, UK, 1992; p. 69, ISBN 0340555122.

68. Villani, G.; Tomei, F.; Tomozeiu, R.; Marletto, V. Climatic scenarios and their impacts on irrigated agriculture in Emilia-Romagna, Italy. Ital. J. Agrometeorol. 2011, 16, 5-17.

69. Ventrella, D.; Charfeddine, M.; Moriondo, M.; Rinaldi, M.; Bindi, M. Agronomic adaptation strategies under climate change for winter durum wheat and tomato in southern Italy: Irrigation and nitrogen fertilization. Reg. Environ. Chang. 2012, 12, 407-419. [CrossRef]

70. Campi, P.; Navarro, A.; Giglio, L.; Palumbo, A.D.; Mastrorilli, M. Modelling for water supply of irrigated cropping systems on climate change. Ital. J. Agron. 2012, 7, 259-265. [CrossRef]

71. Auci, S.; Vignani, D. Climate Change Effects and Agriculture in Italy: A Stochastic Frontier Analysis at Regional Level; MPRA 2014; Paper 53500; University Library of Munich: Munich, Germany, 2014. Available online: https:/ / mpra.ub.uni-muenchen.de/53500/ (accessed on 23 November 2017).

72. Water Framework Directive (WFD). EC Directive 2000/60/EC of the European Parliament and of the Council, Establishing a Framework for Community Action in the Field of Water Policy; FAO: Rome, Italy, 2000.

73. Water Information System Europe (WISE). Water Note 10. Climate Change: Addresssing Floods, Drought and Changing Aquatic Ecosystems. Water Notes on the Implementation of the Water Framework Directive; European Commission (DG Environment): Brussels, Belgium, 2008; ISBN 978-92-79-11039-9. 
74. WWF/CMCC Report Scenari Per L'italia. II Paradosso Climatico Degli Estremi Opposti Nel Futuro Dell'Italia; Elaborazione WWF Italia su Testi a Cura del Gruppo di Lavoro Coordinato da Paola Mercogliano (CMCC); EARTH HOUR: Gland, Switzerland, 2016.

75. Zollo, A.L.; Rillo, V.; Bucchignani, E.; Montesarchio, M.; Mercogliano, P. Extreme temperature and precipitation events over Italy: Assessment of high-resolution simulations with COSMO-CLM and future scenarios. Int. J. Climatol. 2016, 36, 987-1004. [CrossRef]

76. Longobardi, A.; Mautone, M.; De Luca, C. Reservoirs performances under climate variability: A case study. In Evolving Water Resources Systems: Understanding, Predicting and Managing Water-Society Interactions, Proceedings of the ICWRS 2014, Bologna, Italy, 4-6 June 2014; IAHS Publication: Oxford, UK, 2014; Volume 364.

77. Preziosi, E.; Del Bon, A.; Romano, E.; Petrangeli, A.B.; Casadei, S. Vulnerability to drought of a complex water supply system. The upper Tiber basin case study (Central Italy). Water Resour. Manag. 2013, 27, 4655-4678. [CrossRef]

78. Stakhiv, V.; Stewart, B. Needs for Climate Information in Support of Decision-Making in the Water Sector. Procedia Environ. Sci. 2010, 1, 102-119. [CrossRef]

79. ISTAT. Andamento Meteo-Climatico in Italia Anni 2000-2009; Statistiche in Breve: Rome, Italy, 2010.

(C) 2018 by the authors. Licensee MDPI, Basel, Switzerland. This article is an open access article distributed under the terms and conditions of the Creative Commons Attribution (CC BY) license (http:/ / creativecommons.org/licenses/by/4.0/). 